\title{
Pengaruh Perputaran Piutang Terhadap Profitabilitas (Studi Pada Perusahaan Pertambangan Batu Bara Milik Swasta Yang Terdaftar di Bursa Efek Indonesia Periode 2011-2014)
}

\author{
Nazmi Fajrin Nur Kamila \\ Program Studi Pendidikan Akuntansi, FPEB, Universitas Pendidikan Indonesia, Bandung, Indonesia
}

\begin{abstract}
This study aims to determine the effect of Receivable Turnover (RT) on profitability in privately owned coal mining companies listed on the Indonesia Stock Exchange for the 2011-2014 period, where profitability is proxied on Return on Total Assets (ROA). The research method used is descriptive and verification research methods. The data collection technique used is the documentation method. Data in the form of financial statements obtained from the official website of the Indonesia Stock Exchange. The population in this study were 22 privately owned coal mining companies listed on the Indonesia Stock Exchange. The sampling technique used purposive sampling to obtain a sample of 18 companies. Processing data in this study using simple linear regression statistical calculations. Before doing a simple linear regression analysis, a normality test and linearity test were carried out. Furthermore, regression testing is carried out using the $F$ test, then proceed with the significance test of the regression coefficient using the test. Based on the results of statistical processing obtained the ROA regression equation $=1.498974+0.282112$ RT. Through hypothesis testing, the regression equation shows that accounts receivable turnover has a positive effect on profitability with a coefficient of 0.282112 . That is, if the accounts receivable turnover has increased by one time, then profitability will increase by $0.282112 \%$.
\end{abstract}

Keywords. accounts receivable turnover; profitability

\begin{abstract}
Abstrak
Penelitian ini bertujuan untuk mengetahui pengaruh perputaran piutang (Receivable Turnover - RT) terhadap profitabilitas pada perusahaan pertambangan batu bara milik swasta yang terdaftar di Bursa Efek Indonesia periode 2011-2014, dimana profitabilitas diproksikan pada Return on Total Assets (ROA). Metode penelitian yang digunakan adalah metode penelitian deskriptif dan verifikatif. Adapun teknik pengumpulan data yang digunakan adalah metode dokumentasi. Data berupa laporan keuangan yang diperoleh dari situs resmi Bursa Efek Indonesia. Populasi dalam penelitian ini adalah 22 perusahaan pertambangan batu bara milik swasta yang terdaftar di Bursa Efek Indonesia. Teknik pengambilan sampel menggunakan purposive sampling sehingga diperoleh sampel sebanyak 18 perusahaan. Pengolahan data dalam penelitian ini menggunakan perhitungan statistik regresi linier sederhana. Sebelum melakukan analisis regresi linier sederhana, dilakukan uji normalitas dan uji linearitas. Selanjutnya, dilakukan pengujian regresi menggunakan uji F, kemudian dilanjutkan dengan pengujian keberartian koefisien regresi dengan menggunakan uji $t$. Berdasarkan hasil pengolahan statistik diperoleh persamaan regresi $R O A=1,498974+0,282112 R T$. Melalui pengujian hipotesis, persamaan regresi tersebut menunjukkan bahwa perputaran piutang berpengaruh positif terhadap profitabilitas dengan koefisien sebesar 0,282112. Artinya, apabila perputaran piutang mengalami kenaikan sebanyak satu kali maka profitabilitas pun akan meningkat sebesar 0,282112\%.
\end{abstract}

Kata Kunci. perputaran piutang; profitabilitas.

Corresponding author. Email. fajrinnazmi@gmail.com

How to cite this article. N, Kamila. (2017). Pengaruh Perputaran Piutang Terhadap Profitabilitas (Studi Pada Perusahaan Pertambangan Batu Bara Milik Swasta Yang Terdaftar di Bursa Efek Indonesia Periode 20112014 ). Jurnal Pendidikan Akuntansi Dan Keuangan, 5(2), 71-78. Retrieved from http://ejournal.upi.edu/index.php/JPAK/article/view/15405

History of article. Received: Februari 2017, Revision: Mei 2017, Published: Juli 2017

\section{Pendahuluan}

Secara umum tujuan dari setiap perusahaan adalah untuk memperoleh laba dan melangsungkan entitas bisnisnya. Untuk dapat melangsungkan entitas bisnisnya, suatu perusahaan harus berada dalam keadaan menguntungkan atau profitable. Demikian pula halnya untuk perusahaan pertambangan batu 
bara yang terdaftar di Bursa Efek Indonesia. Perusahaan dengan keuntungan atau tingkat pengembalian modal yang tinggi serta dapat terus menerus mempertahankan pertumbuhannya akan menarik minat para investor untuk menanamkan modal. Oleh sebab itu, perusahaan dituntut untuk selalu menjaga dan mengukur kondisi keuangannya agar tetap berada dalam kondisi yang menguntungkan, sehingga investor tertarik dan tetap percaya untuk menanamkan modal.

Untuk mengukur kondisi keuangan suatu perusahaan dapat dilihat melalui kinerja rasio keuangan, diantaranya rasio profitabilitas. Profitabilitas dapat diukur salah satunya dengan menggunakan return on total assets (ROA).

Terdapat 22 perusahaan pertambangan batu bara yang secara resmi telah terdaftar di Bursa Efek Indonesia. Perkembangan ROA 22 perusahaan pertambangan batu bara yang terdaftar di Bursa Efek Indonesia periode 2011 sampai 2014 tersebut cenderung mengalami penurunan. Hal tersebut terlihat dari rata-rata ROA setiap tahunnya. Pada tahun 2011 sampai 2013, rata-rata ROA mengalami penurunan begitu tajam. Walaupun peningkatan sempat terjadi pada tahun 2014, namun peningkatan tersebut tidak sebanding dengan penurunannya. Selain itu, hanya terdapat tiga perusahaan yang nampak mengalami kenaikan dan bernilai positif, sedangkan perusahaan lainnya cenderung mengalami penurunan bahkan bernilai negatif.

Penurunan tingkat ROA tersebut merupakan suatu permasalahan yang harus segera diatasi, karena penurunan pada tingkat ROA menunjukkan bahwa perusahaan mengalami penurunan pada profitabilitasnya. Hal itu berarti manajemen perusahaan belum efisien dalam mengelola aktiva untuk memperoleh keuntungan sehingga nantinya akan berpengaruh pada tingkat kepercayaan investor untuk menanamkan modal.

Profitabilitas sebagai salah satu penilaian kinerja keuangan dapat mengalami peningkatan ataupun penurunan karena dipengaruhi oleh berbagai macam faktor. Menurut Syamsuddin (2009:59) faktor-faktor yang mempengaruhi profitabilitas antara lain adalah volume penjualan, modal kerja, total aktiva, modal sendiri, dan faktor lainnya.
Modal kerja adalah salah satu faktor yang mempengaruhi profitabilitas. Hal tersebut sesuai dengan pendapat Ambarwati (2010:112) yang menyatakan bahwa "Modal kerja adalah modal yang seharusnya tetap ada dalam perusahaan sehingga operasional perusahaan menjadi lebih lancar serta tujuan akhir perusahaan untuk menghasilkan laba akan tercapai". Modal kerja itu sendiri merupakan investasi jangka pendek perusahaan yang terdiri dari seluruh aktiva lancar atau kas, piutang, persediaan, dan surat berharga.

Dalam penelitian ini profitabilitas dapat dilihat dari jumlah modal yang tertanam dalam piutang. Denčić-Mihajlov (2013) menyatakan bahwa "Accounts receivable management is a crucial filed of corporate finance because of its effects on a firm's profitability and risk, and consequently on the firm's value". Untuk dapat mengelola piutang dengan baik, perusahaan harus mengatur kecepatan piutang untuk dapat ditagih kembali yang ditunjukkan dengan tingkat perputaran piutang.

Pada dasarnya selama perusahaan masih beroperasi piutang selalu dalam keadaan berputar. Menurut Sawir (2005:198), "Semakin besar perputaran piutang maka semakin besar risiko, tetapi bersamaan dengan itu memperbesar profitabilitasnya" Sejalan dengan pendapat tersebut, dapat dikatakan bahwa perputaran piutang menjadi salah satu faktor yang mempengaruhi profitabilitas.

Melalui pengukuran perputaran piutang maka akan dapat diketahui hubungan dan kontribusinya dalam mendukung kelancaran aktivitas operasional perusahaan serta mencapai tingkat profitabilitas yang diharapkan perusahaan.

\section{Landasan Teori \\ Perputaran Piutang}

Fraser \& Ormiston (2008:231) menyatakan bahwa "Perputaran piutang usaha mengukur berapa kali, rata-rata, piutang usaha ditagih secara tunai selama tahun yang bersangkutan".

Menurut Munawir (2007:75) penurunan pada tingkat perputaran piutang dapat disebabkan oleh turunnya penjualan dan naiknya piutang, turunnya piutang dan diikuti 
turunnya penjualan dalam jumlah lebih besar, naiknya penjulan dan diikuti naiknya piutang dalam jumlah lebih besar, turunnya penjualan dengan piutang yang tetap, dan naiknya piutang sedangkan penjualan tidak berubah.

Harahap (2008:308) menyatakan bahwa semakin besar tingkat perputaran piutang semakin baik karena penagihan piutang dilakukan dengan cepat. Namun, Harnanto (2004:194) menyatakan bahwa sebaiknya tingkat perputaran piutang berkisar antara 10 kali hingga 15 kali. Menanggapi pernyataan tersebut, Munawir (2007:75) berpendapat bahwa semakin tinggi perputaran piutang menunjukkan modal kerja yang ditanam dalam piutang rendah, sebaliknya jika semakin rendah ada over investment.

Untuk menghitung perputaran piutang dapat menggunakan rumus :

$$
\text { Perputaran Piutang }=\frac{\text { Penjualan Bersih }}{\text { Piutang Usaha }}
$$

(Fraser \& Ormiston, 2008:334)

\section{Profitabilitas}

Fraser \& Ormiston (2008:351) menyatakan bahwa "Rasio profitabilitas adalah suatu rasio yang mengukur kinerja keseluruhan suatu perusahaan dan efisiensinya dalam mengelola aktiva, kewajiban dan ekuitas".

Kasmir (2008:197) menjelaskan bahwa tujuan dari penggunaan rasio profitabilitas bagi pihak perusahaan maupun bagi pihak luar perusahaan adalah untuk mengukur atau menghitung laba yang diperoleh perusahaan dalam satu periode tertentu, untuk menilai posisi laba perusahaan tahun sebelumnya dengan tahun sekarang, untuk menilai perkembangan laba dari waktu ke waktu, untuk menilai besarnya laba bersih sesudah pajak dengan modal sendiri, dan untuk mengukur produktifitas seluruh dana perusahaan yang digunakan baik modal pinjaman maupun modal sendiri.

Menurut Margaretha (2011:26) untuk mengukur profitabilitas dapat dihitung dengan rumus :
a. $\quad$ Net profit margin on sales $=$ $\frac{\text { Earning After Tax }}{\text { Sales }}$
b. Return on total assets $(R O A)=$ Earning After Tax

\section{c. $\quad$ Return on equity $(R O E)=$ Earning After Tax \\ $\overline{\text { Common Equity-Prefered Stock }}$}

Dalam penelitian ini profitabilitas diukur dengan menggunakan Return on total assets (ROA). Menurut Gitman (2009:68), "ROA measure the overall effectiveness of management in generating profits with its available assets".

Untuk menghitung ROA dapat menggunakan rumus :

$$
\begin{aligned}
& \text { Return on total assets }(\text { ROA }) \\
& \qquad=\frac{\text { Earning After Tax }}{\text { Total Assets }} \\
& \text { (Margaretha, 2011:26) }
\end{aligned}
$$

ROA penting bagi pihak manajemen sebagai alat untuk mengevaluasi efektivitas dan efisiensi manajemen perusahaan dalam mengelola seluruh aktiva perusahaan. Menurut Kasmir (2008: 63) kesimpulan tentang baik tidaknya tingkat ROA hanya dapat diketahui sesudah diperbandingkan dengan rata-rata industrinya. Pendapat lain menyatakan bahwa standar ROA yang sehat adalah minimal 9\% (Brigham \& Houston, 2013:109). Semakin tinggi ROA berarti menunjukkan kinerja yang baik atau semakin efisien penggunaan aktiva oleh perusahaan.

\section{Hubungan Perputaran Piutang dengan Profitabilitas}

Piutang merupakan komponen modal kerja yang berkaitan langsung dengan kegiatan operasional perusahaan. Pengelolaan piutang yang baik akan berpengaruh terhadap keuntungan perusahaan dan pada akhirnya akan mempengaruhi profitabilitas.

Pada dasarnya aktiva lancar suatu perusahaan, dalam hal ini modal kerja, termasuk piutang, selalu dalam keadaan berputar selama perusahaan tersebut masih beroperasi. Keadaan berputar tersebut harus dijaga perusahaan agar terhindar dari terjadinya risiko kerugian piutang.

Perputaran piutang adalah rasio yang digunakan untuk mengukur kecepatan piutang untuk dapat ditagih kembali dalam satu periode. Semakin tinggi perputaran piutang maka semakin baik, karena tingginya perputaran piutang menunjukkan bahwa perusahaan semakin baik dalam melakukan pengelolaan piutang. Menurut Sawir 
(2005:198), "Semakin besar perputaran piutang maka semakin besar risiko, tetapi bersamaan dengan itu memperbesar profitabilitasnya". Selain itu, berdasarkan hasil penelitiannya, Yuliani (2013) menyatakan bahwa, "Semakin cepat tingkat perputaran piutang maka profitabilitasnya pun semakin meningkat".

Ketika tingkat perputaran piutang tinggi artinya piutang dapat ditagih dengan cepat dan akan lebih cepat berubah menjadi kas. Kemudian kas tersebut dapat dimanfaatkan untuk terus melangsungkan kegiatan operasional perusahaan dan untuk aktivitas lain yang dapat memberikan keuntungan bagi perusahaan, sehingga pada akhirnya dapat meningkatkan profitabilitas perusahaan. Sebaliknya, ketika tingkat perputaran piutang rendah artinya piutang tidak dapat ditagih dengan cepat dan tidak dapat berubah menjadi kas dengan cepat pula, kegiatan operasional perusahaan pun akan terhambat sehingga perusahaan lambat memperoleh laba dan pada akhirnya tingkat profitabilitas perusahaan akan menurun.

Beberapa hasil penelitian mengungkapkan bahwa perputaran piutang berpengaruh positif terhadap profitabilitas yang diproksikan pada ROA, walaupun tidak signifikan (Denčić-Mihajlov, 2013). Oleh sebab itu, perputaran piutang merupakan hal yang penting bagi perusahaan karena tinggi rendahnya tingkat perputaran piutang akan berdampak langsung terhadap profitabilitas perusahaan.

\section{Metode Penelitian}

Metode penelitian yang digunakan adalah metode penelitian deskriptif dan verifikatif. Sementara variabel yang dijadikan sebagai objek penelitian, yaitu Perputaran Piutang (Variabel Independen). Profitabilitas (Variabel Dependen) Dalam penelitian profitabilitas diproksikan pada Return on Total Assets (ROA).

Populasi dalam penelitian ini adalah 22 perusahaan pertambangan batu bara yang terdaftar di Bursa Efek Indonesia. Teknik sampling yang digunakan dalam penelitian ini adalah purposive sampling. Sampel pada penelitian ini disesuaikan dengan pertimbangan (1) Perusahaan pertambangan batu bara milik swasta yang terdaftar di Bursa Efek Indonesia
(2) Perusahaan yang mengumumkan laporan keuangan secara lengkap dari tahun 2011-2014.

Berdasarkan pertimbangan tersebut maka didapat 18 perusahaan yang digunakan sebagai sampel dalam penelitian ini dengan 72 data observasi. Dalam penelitian ini data yang digunakan adalah data sekunder. Adapun teknik pengumpulan data dalam penelitian ini menggunakan metode dokumentasi.

Untuk memperoleh gambaran mengenai pengaruh perputaran piutang terhadap profitabilitas, maka perlu dilakukan analisis terhadap data-data yang diperoleh. Langkah-langkah analisis yang dilakukan dalam penelitian ini meliputi :

\section{Analisis Deskriptif}

Dalam menganalisis data deskriptif, tentukan rasio-rasio variabel untuk memperoleh gambaran mengenai kondisi kedua variabel yang diteliti agar diperoleh nilai dengan menggunakan alat analisis sebagai berikut :

a) Perputaran Piutang (Variabel Independen)

Perputaran Piutang

$$
=\frac{\text { Penjualan Bersih }}{\text { Piutang Usaha }}
$$

(Fraser \& Ormiston, 2008:334)

b) Profitabilitas (Variabel Dependen)

Return on total assets (ROA)

$$
=\frac{\text { Earning After Tax }}{\text { Total Assets }}
$$

Setelah memperoleh gambaran mengenai kondisi kedua variabel, selanjutnya dilakukan analisis statistik deskriptif untuk tiap variabel dengan langkah Menghitung Nilai Rata-Rata dan Menghitung Nilai Maksimum dan Nilai Minimum

\section{Analisis Inferensial}

Teknik analisis data dalam penelitian ini bersifat data panel. Nachrowi \& Usman (2006:311) menjelaskan bahwa untuk mengestimasi parameter model dengan data panel, terdapat beberapa teknik yang ditawarkan, yaitu (1) Koefisien Tetap antar Waktu dan Individu (Common Effect/Ordinary Least Square0 (2) Model Efek Tetap (Fixed Effect) (3) Model Efek Acak (Random Effect) 


\section{Pengujian Hipotesis Penelitian}

Adapun langkah-langkah pengujian hipotesis yang dilakukan dalam penelitian ini meliputi Pemilihan Teknik Estimasi Regresi Data Panel terdiri dari (1) Uji Signifikansi Fixed Effect Melalui uji F Statistik/Uji Chow (2) Uji Signifikansi Random Effect Melalui Uji Lagrange Multiplier (Uji LM) (3) Uji Signifikansi Fixed Effect atau Random Effect Melalui Hausman Test

Uji Asumsi Klasik. Uji normalitas yang digunakan dalam penelitian ini yaitu uji Jarque-Bera dengan menggunakan Eviews 8. Uji linearitas yang digunakan dalam penelitian ini yaitu Ramsey RESET Test dengan menggunakan Eviews 8.

\section{Regresi Linier Sederhana}

Analisis regresi akan memberikan gambaran (prediksi) besarnya nilai profitabilitas jika perputaran piutang berubah, baik ketika mengalami kenaikan maupun penurunan. Analisis regresi yang digunakan dalam penelitian ini adalah regresi linier sederhana.

\section{Uji Keberartian Regresi (Uji F)}

Pengujian ini dimaksudkan untuk meyakinkan apakah persamaan regresi linier dalam penelitian ini berarti atau tidak berarti, sehingga dapat digunakan untuk membuat kesimpulan.

\section{Uji Keberartian Koefisien Regresi (Uji $t$ )}

Selain uji F perlu juga dilakukan uji $t$ untuk mengetahui keberartian koefisien regresi atau dengan kata lain untuk menguji pengaruh variabel penelitian.

\section{Hasil Dan Pembahasan}

Gambaran Perputaran Piutang Perusahaan Pertambangan Batu Bara Milik Swasta yang Terdaftar di Bursa Efek Indonesia Periode 2011-2014

Tingkat perputaran piutang perusahaan pertambangan batu bara milik swasta yang terdaftar di Bursa Efek Indonesia periode 2011 sampai dengan 2014 berfluktuatif cenderung mengalami penurunan dengan tingkat rata-rata perputaran piutang 11,97 kali. Hal tersebut menunjukkan bahwa piutang perusahaan pertambangan batu bara milik swasta yang terdaftar di Bursa Efek Indonesia periode 2011 sampai dengan 2014 dapat ditagih dalam bentuk kas, kemudian kembali menjadi piutang sebanyak 11,97 kali. Merujuk pada pernyataan Harnanto (2004:194), rata-rata tingkat perputaran piutang tersebut berada pada kondisi yang baik karena berputar pada rentang antara 10 hingga 15 kali. Namun, jika dilihat lebih lanjut secara rata-rata terdapat 15 perusahaan dengan tingkat perputaran piutang di bawah standar ideal.

\section{Gambaran Profitabilitas Perusahaan Pertambangan Batu Bara Milik Swasta yang Terdaftar di Bursa Efek Indonesia Periode 2011-2014}

Tingkat ROA perusahaan pertambangan batu bara milik swasta yang terdaftar di Bursa Efek Indonesia periode 2011 sampai dengan 2014 cenderung mengalami penurunan setiap tahunnya dengan tingkat ratarata ROA sebesar 4,87\%. Hal tersebut menunjukkan bahwa $4,87 \%$ dari total laba yang diperoleh perusahaan pertambangan batu bara milik swasta yang terdaftar di Bursa Efek Indonesia periode 2011 sampai dengan 2014 dihasilkan oleh total aktiva yang dimilikinya. Jika merujuk pada pendapat Brigham \& Houston (2013:109), rata-rata tingkat ROA perusahaan tersebut berada pada kondisi yang tidak sehat karena kurang dari 9\%. Bahkan jika dilihat lebih lanjut berdasarkan standar minimal ROA dan nilai rata-rata tersebut, terdapat 14 perusahaan berada pada kondisi yang tidak sehat.

\section{Pengujian Hipotesis Penelitian}

\section{Analisis Regresi Linear Sederhana}

Berikut tabel 1 terkait hasil pengolahan analisis regresi linear sederhana data panel mengikuti Random Effect Model dengan menggunakan Eviews 8.

Berdasarkan tabel 1 dapat diketahui bahwa nilai konstanta $\left(\beta_{0}\right)$ adalah sebesar 1,573940, sementara nilai koefisien perputaran piutang $\left(\beta_{1}\right)$ adalah sebesar 0,279333. Dengan demikian dapat dirumuskan persamaan regresi linear sederhana sebagai berikut:

$$
R O A=1,573940+0,279333 R T
$$




\section{Uji Keberartian Regresi (Uji F)}

Berdasarkan hasil pengolahan data pada tabel 1, dapat diketahui bahwa nilai $F_{\text {hitung }}$ sebesar 6,504007, sedangkan nilai $F_{\text {tabel }}$ pada tingkat signifikansi $5 \%$ dengan $\mathrm{dk}$ pembilang $=1$ dan $\mathrm{dk}$ penyebut $=70$ adalah sebesar 3,98. Dengan demikian nilai $F_{\text {hitung }}>$ nilai $F_{\text {tabel }}$, maka dapat disimpulkan bahwa regresi berarti. Hal tersebut menunjukan bahwa model regresi dalam penelitian ini dapat dipakai untuk membuat kesimpulan.

\section{Uji Keberartian Koefisien Regresi (Uji $t$ )}

Berdasarkan hasil pengolahan data pada tabel 1, dapat diketahui bahwa nilai $t_{\text {hitung }}$ untuk perputaran piutang sebesar 2,585122 , sedangkan nilai $t_{\text {tabel }}$ pada tingkat signifikansi $5 \%$ dengan $\mathrm{dk}=70$ adalah sebesar 1,66691. Dengan demikian nilai $t_{\text {hitung }}>$ $t_{\text {tabel }}$, maka dapat disimpulkan bahwa perputaran piutang berpengaruh positif terhadap profitabilitas.

\section{Pembahasan Hasil Penelitian}

Berdasarkan data serta penjelasan yang telah dipaparkan sebelumnya, dapat diketahui gambaran mengenai kondisi perputaran piutang dan profitabilitas perusahaan pertambangan batu bara milik swasta yang terdaftar di Bursa Efek Indonesia periode 2011 sampai dengan 2014. Pada periode tersebut tingkat perputaran piutang perusahaan berfluktuasi cenderung mengalami penurunan dengan tingkat rata-rata perputaran piutang 11,97 kali. Hal tersebut menunjukkan bahwa piutang perusahaan pertambangan batu bara milik swasta yang terdaftar di Bursa Efek Indonesia periode 2011 sampai dengan 2014 dapat ditagih dalam bentuk kas, kemudian kembali menjadi piutang sebanyak 11,97 kali.

Berdasarkan standar ideal tingkat perputaran piutang dan nilai rata-rata industri, terdapat delapan perusahaan dengan tingkat perputaran piutang di bawah standar ideal selama kurun waktu empat tahun, yaitu PT ATPK Resources Tbk (ATPK), PT Bayan Resources Tbk (BYAN), PT Darma Henwa Tbk (DEWA), PT Delta Dunia Makmur Tbk (DOID), PT Garda Tujuh Buana Tbk (GTBO), PT Perdana Karya Perkasa Tbk (PKPK), PT
Petrosea Tbk (PTRO), dan PT Toba Bara Sejahtera Tbk (TOBA). Sedangkan perusahaaan yang berada pada kisaran standar ideal tingkat perputaran piutang selama kurun waktu empat tahun, yaitu PT Indo Tambangraya Megah Tbk (ITMG) dan PT Samindo Resources Tbk (MYOH). Perusahaan dengan tingkat perputaran piutang kurang dari 10 kali berarti memiliki over investment dalam piutang, sedangkan perusahaan dengan tingkat perputaran piutang lebih dari 15 kali berarti modal kerja yang ditanam dalam piutang rendah, dan perusahaan dengan pencapaian tingkat perputaran piutang pada rentang antara 10 hingga 15 kali berarti perusahaan tersebut telah mampu mengelola piutang dengan baik.

Mengenai gambaran kondisi profitabilitas, pada periode tersebut rata-rata tingkat ROA mengalami penurunan setiap tahunnya dengan tingkat rata-rata ROA sebesar $4,87 \%$. Hal tersebut menunjukkan bahwa $4,87 \%$ dari total laba yang diperoleh perusahaan pertambangan batu bara milik swasta yang terdaftar di Bursa Efek Indonesia periode 2011 sampai dengan 2014 dihasilkan oleh total aktiva yang dimilikinya.

Berdasarkan standar minimal ROA, terdapat delapan perusahaan yang berada pada kondisi tidak sehat karena pencapaian tingkat ROA kurang dari 9\% selama empat tahun berturut-turut, yaitu PT Atlas Resources Tbk (ARII), PT ATPK Resources (ATPK), PT Berau Coal Energy Tbk (BRAU), PT Baramulti Suksessarana Tbk (BSSR), PT Bumi Resources Tbk (BUMI), PT Darma Henwa Tbk (DEWA), PT Delta Dunia Makmur Tbk (DOID), dan PT Perdana Karya Perkasa Tbk (PKPK). Sedangkan perusahaan yang dinilai sehat selama empat tahun berturut-turut, yaitu PT Indo Tambangraya Megah Tbk (ITMG). Perusahaan dengan pencapaian tingkat ROA kurang dari $9 \%$ berarti belum efisien dalam mengelola aktiva untuk menghasilkan laba, sedangkan perusahaan dengan pencapaian tingkat ROA lebih dari $9 \%$ berarti telah efisien dalam mengelola aktiva untuk menghasilkan laba.

Selanjutnya, berdasarkan hasil penelitian melalui pengujian hipotesis dengan menggunakan regresi linier sederhana untuk mengetahui gambaran (prediksi) besarnya pengaruh perputaran piutang terhadap profitabilitas, diperoleh persamaan regresi 
$R O A=1,498974+0,282112 R T$. Persamaan regresi tersebut telah diperoleh keberartiannya dengan menggunakan uji $F$. Melalui uji $F$ tersebut, diperoleh nilai $F_{\text {hitung }}$ sebesar 6,504007, sedangkan nilai $F_{\text {tabel }}$ sebesar 3,98. Nilai tersebut menunjukkan bahwa $F_{\text {hitung }}>$ nilai $F_{\text {tabel }}$, hal tersebut berarti bahwa model regresi dalam penelitian ini dapat dipakai untuk membuat kesimpulan.

Selain itu, hasil dari pengujian keberartian koefisien regresi dengan menggunakan uji $t$, diperoleh nilai $t_{\text {hitung }}$ untuk perputaran piutang sebesar 2,585122 , sedangkan nilai $t_{\text {tabel }}$ sebesar 1,66691. Nilai tersebut menunjukkan bahwa nilai $t_{\text {hitung }}>t_{\text {tabel }}$, menyatakan bahwa perputaran piutang berpengaruh positif terhadap profitabilitas dengan koefisien sebesar 0,282112. Pengaruh positif tersebut menunjukkan bahwa perputaran piutang memiliki hubungan yang searah dengan profitabilitas. Hal tersebut berarti apabila perputaran piutang mengalami kenaikan sebanyak satu kali maka profitabilitas pun akan meningkat sebesar $0,282112 \%$ (dengan asumsi variabel lainnya bernilai konstan). Hal tersebut sejalan dengan teori rujukan peneliti yang dinyatakan oleh Sawir (2005:198) bahwa, "Semakin besar perputaran piutang maka semakin besar risiko, tetapi bersamaan dengan itu memperbesar profitabilitasnya".

Pengaruh positif yang dihasilkan penelitian ini dapat dibuktikan oleh pencapaian PT Indo Tambangraya Megah Tbk yang memiliki tingkat perputaran piutang ideal selama empat tahun berturut-turut dengan ratarata 11,60 kali. Kondisi perputaran piutang yang baik tersebut diikuti oleh tingginya ratarata ROA yaitu sebesar $23,58 \%$. Bersumber dari laporan tahunan PT Indo Tambangraya Megah Tbk, hal tersebut dialami perusahaan karena sebesar $92 \%$ dari piutang usaha perusahaan bersifat lancar, artinya perusahaan telah berhasil mengelola piutang dengan baik melalui pengaturan tingkat perputaran piutang dan kebijakan kredit yang diterapkan. Selanjutnya, perusahaan juga telah berhasil melakukan upaya-upaya efisiensi operasional dalam melakukan penjualan sehingga berpengaruh pada tingkat profitabilitas.

Sementara, kondisi sebaliknya dialami oleh PT Perdana Karya Perkasa Tbk yang memiliki tingkat perputaran piutang di bawah standar ideal selama kurun waktu empat tahun dengan rata-rata 3,39 kali. Tingkat perputaran piutang yang kurang baik tersebut diikuti pula oleh rendahnya rata-rata ROA yaitu sebesar 3,24\%. Bersumber dari laporan tahunan PT Perdana Karya Perkasa Tbk, hal tersebut terjadi dikarenakan perusahaan mengalami penurunan piutang usaha akibat penurunan pendapatan usaha dan penurunan pekerjaan dalam pelaksanaan sehingga profitabilitas pun ikut menurun.

Meskipun profitabilitas dipengaruhi oleh berbagai macam faktor, namun dengan melakukan pengelolaan piutang melalui pengaturan perputaran piutang yang baik maka akan berpengaruh terhadap keuntungan perusahaan, sehingga pada akhirnya akan mempengaruhi profitabilitas. Ketika perusahaan telah mengetahui tingkat perputaran piutang, perusahaan dapat melihat gambaran tentang kualitas piutang dan kesuksesan dalam penagihan piutang yang telah dilakukannya. Hal tersebut pada akhirnya menjadi informasi yang dapat dipertimbangkan manajemen perusahaan dalam mengambil keputusan agar perusahaan berada dalam posisi yang menguntungkan.

\section{Kesimpulan}

Berdasarkan hasil penelitian yang telah dilakukan, maka dapat ditarik kesimpulan yaitu (1) Perputaran piutang perusahaan pertambangan batu bara milik swasta yang terdaftar di Bursa Efek Indonesia periode 2011 sampai dengan 2014 berfluktuasi cenderung mengalami penurunan dengan tingkat rata-rata perputaran piutang 11,97 kali. (2) Profitabilitas perusahaan pertambangan batu bara milik swasta yang terdaftar di Bursa Efek Indonesia periode 2011 sampai dengan 2014 cenderung mengalami penurunan dengan tingkat rata-rata ROA sebesar 4,87\%. (3) Perputaran piutang berpengaruh positif terhadap profitabilitas dengan koefisien sebesar 0,282112. Artinya, apabila perputaran piutang mengalami kenaikan sebanyak satu kali maka profitabilitas pun akan meningkat sebesar $0,282112 \%$. 


\section{Daftar Pustaka}

Ambarwati, S. D. A. (2010). Manajemen Keuangan Lanjutan. Yogyakarta: Graha Ilmu.

Brigham, E. F., dan Houston, J. F. (2013). Dasar-Dasar Manajemen Keuangan, Edisi Kesebelas. Jakarta: Erlangga.

Denčić-Mihajlov, K. (2013). "Impact of account receivable management on the profitability of the Serbian companies during the financial crisis". 9th International ASECU Conference on "Systemic Economic Crisis: Current Issue and Perspective”.

Fraser, L. M., dan Ormiston, A. (2008). Memahami Laporan Keuangan, Edisi Ketujuh. Jakarta: Indeks.

Gitman, L. J. (2006). Principles of Managerial Finance. United States: Pearson Education, Inc.

Harahap, S. S. (2008). Analisis Kritis atas Laporan Keuangan. Jakarta: PT RajaGrafindo Persada.

Harnanto. (2004). Analisis Laporan Keuangan. Yogyakarta: UUP AMP YKPN.

Kasmir. (2008). Analisis Laporan Keuangan. Jakarta: PT RajaGrafindo Persada.

Margaretha, F. (2011). Manajemen Keuangan Untuk Manajer Nonkeuangan. Jakarta: Erlangga.

Munawir, S. (2007). Analisa Laporan Keuangan. Yogyakarta: Liberty.

Nachrowi, N. D., dan Usman, H. (2006). Pendekatan Populer dan Praktis Ekonometrika Untuk Analisis Ekonomi dan Keuangan. Depok: Lembaga Penerbit Fakultas Ekonomi Universitas Indonesia.

Sawir, A. (2005). Analisis Kinerja Keuangan dan Perencanaan Keuangan. Jakarta: Gramedia Pustaka Utama.

Syamsuddin, L. (2009). Manajemen Keuangan Perusahaan. Jakarta : PT RajaGrafindo Persada.

Yuliani, R. (2013). “Pengaruh perputaran piutang terhadap profitabilitas pada perusahaan PT Unilever Indonesia Tbk tahun 2005-2012". Jurnal Ilmiah
Mahasiswa Fakultas Ekonomi dan Bisnis Universitas Brawijaya. Volume 1 No. 2

Semester Genap 2012/2013. 